\title{
Cluster-based Innovation Policies: A Critical Approach
}

\author{
Asst. Prof. Dr. Ayșe Saime Döner (Beykent University, Turkey)
}

\begin{abstract}
Following the shift to a knowledge-based economy, designing and implementing the right institutions relevant to knowledge production has become the main concern of national industrial policies. Regional clustering appears as a commonly adopted policy tool to promote innovation in developed countries as well as in developing countries. In this regard, this paper examines innovation process in detail and explores the instruments that cluster-based innovation policies must support for promoting innovation. Innovation process may require particular coordination mechanisms at cognitive, institutional and social levels. I first draw a conceptual framework to define the essential aspects that need to be favored by innovation policies. This framework is then used to propose instruments of cluster-based innovation policies. While the idea of regional innovation clusters is mainly based on the geographical dimension of successful innovative activities, the success of clusters depends essentially on coordination mechanisms among the actors involved in the innovation process. Putting forward mostly financial incentives for companies isn't enough for clusters to sustain innovation. These clusters may only continue to promote transient innovation activities and not become the focal of a "learning region", unless they get embedded into a more complex relational setup.
\end{abstract}

\section{Introduction}

Innovation is today largely recognized as the driving force behind productivity and competitiveness of firms and industries, and thus economic growth of regions and nations. Accordingly, policies promoting innovation have gained high popularity among policy makers. These policies, mostly based on the arguments developed by "regional innovation system" literature (Cooke 1992; Cooke et al. 1997; Asheim \& Gertler 2005; Asheim 2007), involves different actors from different backgrounds, such as firms, universities, research labs and even regulatory bodies. Indeed, value-adding innovations require complementary assets which are hardly held by a single actor. Networking and collaboration between these actors as well as coordinating innovative activities are considered crucial elements as the latter entail more and more complexity, costs and risks. There is a widespread agreement in academic literature that geographical proximity facilitates building collaborative relationships and helps to reduce costs of innovative activities. Furthermore, some successful regional models, like Silicon Valley in USA or Sophia Antipolis in France, evidence the prolific relation between geographical proximity and innovation. In this regard, economic-policy makers in many countries have been introducing a regional dimension to their innovation policies (Fritsch \& Stephan 2005).

There is a large body of literature which emphasizes the importance of regions in innovative activities. Studies developing concepts like "milieu innovateur" (Aydalot 1986; Camagni 1991), industrial districts (Becattini 1992; Brusco 1986), regional innovation systems (Cooke et al. 1997; Cooke 2001; Asheim \& Gertler 2005; Asheim et al. 2007) and learning regions (Morgan 1997) put forward the role of geographical proximity in new knowledge generation process. These studies emphasize that knowledge spillovers, which are regarded as the key factor to foster innovative activities, are geographically identifiable, but certainly not granted by solely geographical proximity. Knowledge sharing actually requires cognitive, social and institutional commonalities facilitating communication between actors. Policy makers, observing success stories of territorial innovation models like Silicon Valley and Sophia Antipolis, have implemented innovation policies copying these best practices. However, there is no "one-size-fits-all" regional innovation policy model (Tödtling \& Trippl 2005; Asheim et al. 2011). Each country or each region needs a strategy specifically tailored at its particular characteristics. Nevertheless, it is possible to identify some political instruments and tools that would encourage the formation of a sustainable innovation cluster (Benner 2009). These instruments and tools need formulating with respect to the requirements of innovation process. As studies analyzing innovation or more generally knowledge generation process point out, innovation is an interactive process (Lundvall 1988; Morgan 1997; Foray \& Lundvall 1998; Breschi \& Lissoni 2001; Foray 2004; Antonelli 2005; Lundvall 2009) and thus any policy attempting to promote innovation should not ignore the social dimension of these activities. Hence, cluster-based innovation policies must support both cognitive and social requirements of innovation process. Considering these requirements, this paper provides a critical approach to cluster-based innovation policies and attempts to describe necessary coordination mechanisms to be favored by these. We start by examining the innovation process and more generally the new knowledge generation and the knowledge spillover mechanism, which is at the heart of the localization argument. In this regard, innovation process is examined in order to define the required conditions to be satisfied by the relevant policies. Based on these requirements, examples of instruments and tools that cluster -based innovation policies must support or implement are defined. 


\section{Knowledge Generation Process}

Today knowledge is viewed as the principal resource for firms' productivity, industries' competitiveness and nations' economic growth. The economies are more and more dependent on the production, distribution and use of knowledge. Output and employment grow in knowledge-intensive sectors like high-technology industries. Thus, investment expenditures related to high-technology goods and services, research and development activities, training of the labor force increase. Labor demand is also characterized by knowledge-based jobs. These trends, demonstrating the arrival of knowledge-based economy, cause also changes in economic theories and models. Knowledge is no longer treated as an exogenous variable, but directly incorporated into production functions. However, the very nature of knowledge, such as being abundant instead of scarce but asymmetrically distributed among economic actors, complicates the task of including it into standard economic production function. Hence, efforts for understanding the economic characteristics of knowledge, including the generation and use of knowledge in economic systems, lead to the emergence of a new discipline called the economics of knowledge (Foray \& Lundvall 1998; Foray 2004; Antonelli 2005). This new discipline, which introduces knowledge as an economic good, analyzes and discusses institutions, technologies and social regulations that can promote efficient production and use of knowledge. It doesn't however offer a unified perspective, given that scholars don't come to an agreement about the appropriability level of knowledge, i.e. the ability of agents to capture the returns of their efforts once the knowledge is created. While knowledge is considered a public good in the Arrovian approach, Nelson and Winter (1982) regard it as a quasi-private good. Finally, knowledge is more and more viewed as a localized, collective and complex, path dependent activity (Antonelli 2005). Knowledge generation process and specifically, innovation process can also be defined with respect to these approaches.

Within the Arrovian frame, knowledge is viewed as a public good for the high levels of non-excludability and non-rivalry. In this context, there is no incentive for economic actors to invest in innovative activities, as these actors can't guarantee ownership of their innovation and its pecuniary benefits. Therefore, following a top-down view, scientific knowledge is mainly generated in universities and other public research centers, while corporations undertake the generation of technological knowledge, which is basically the result of the application of new scientific discoveries(Arrow 1962; Nelson 1959). This top-down approach of innovation process is challenged, when Nelson and Winter (1982) argue that knowledge must be regarded as a quasi-private good with high levels of natural excludability. In this perspective, knowledge originates in a tacit form and is acquired by means of learning processes. Tacit knowledge, unlike codified knowledge, is hard to be shared and remains "sticky" to the locus of generation (Von Hippel 1994; Polanyi 1958), which ensures a high level of appropriability. Only once it is articulated and codified, it can be shared with "outsiders". In this approach, knowledge generation and diffusion follow a bottom-up process. Scientific knowledge thus come after technological knowledge which is mostly created in firms. Hence, the latter is considered as the locus where technological and organizational knowledge emerges via integration of learning processes and formal research and development activities.

With the re-discovery of external knowledge as an important input in the knowledge generation process, the third approach comes to appear in the 1990s (Lundvall 1988; Cooke 1992; Lundvall \& Johnson 1994; Asheim 1996). According to this approach, new knowledge is created by combining complementary bits of knowledge held usually by heterogeneous agents. Knowledge generation process thus requires intentional and continual efforts of these interacting agents who, at least, belong to a community of practice and understanding. This new understanding of knowledge as a collective activity highly relates to the role of geographical proximity in the circulation of knowledge (Feldman 1994; Audretsch \& Feldman 1996). Nevertheless, being closely located isn't enough to easily exchange knowledge. Absorptive capacity of agents (Cohen \& Levinthal 1990; Tsai 2001; Nooteboom et al. 2007), institutional proximity (Torré \& Gilly 1999; Boschma 2005) and social proximity (Granovetter 1985, 2005) are important factors that facilitate the exchange of knowledge. These factors also prove to be crucial regarding the knowledge spillovers, which are argued to play a key role in innovative capabilities of localized agents. However, cognitive proximity is rather avoided, since the variety in knowledge bases of these actors proves to be crucial in innovation (Frenken et al. 2007; Boschma \& Iammarino 2009; Asheim et al. 2011). Too much cognitive proximity may indeed hinder the innovative process, since it doesn't offer something new to neither parties (Nooteboom 2000; Nooteboom et al. 2007). Furthermore, the efficiency of generation and dissemination of new knowledge is strongly affected by the network architecture of the interacting agents. Antonelli (2005) argues that while geodesic networks, where each agent is directly linked to each other agent, hamper the dissemination of new knowledge because of high communication costs, centered networks, which are based upon interconnected hubs, facilitate the knowledge flows between agents.

It is today largely acknowledged that innovation process is a collective and complex activity and that geographical proximity plays a key role in this process. Cluster-based innovation policies are thus developed and implemented taking into account this approach. By the means of these policies, policymakers are also hoping to take advantage of knowledge spillovers which are believed to increase the efficiency of innovation activities. Knowledge spillovers are defined as an externality, by which one or a few agents investing in knowledge 
activities, like research or technology development, will end up facilitating other agents' innovation efforts. As several empirical works evidence, it is largely recognized that knowledge flows more easily among agents located within the same area and thus, knowledge spillovers are actually locally bounded (Jaffe 1989; Acs et al. 1992; Jaffe et al. 1993; Acs et al. 1994; Feldman \& Florida 1994; Audretsch \& Feldman 1996; Feldman 1999). However, as Breschi and Lissoni (2001) point out, for knowledge spillovers to exist, some specific conditions other than spatial proximity have to be met. As mentioned earlier, knowledge generation process requires some special institutional, social and cognitive arrangements. The same rules go for the knowledge spillovers as well. Here, we strongly suggest that knowledge spillover is not an unintentional activity but requires intentional and deliberate efforts of both the "spilling" and the recipient. In this regard, we insist that knowledge spillovers occur, when people or firms not responsible for the original investment of the creation of the knowledge benefit from this knowledge (Almeida \& Kogut 1999; Rondé \& Hussler 2005). Thus, building clusters where firms, research institutes and other agents are closely located isn't enough to create knowledge spillovers. Only in the frame of an adapted institutional and organizational context, the geographical proximity implies cognitive interactions (Torré \& Gilly 1999). Institutions are described as "rules of the game" that constrain and shape human interactions (North 1990). They can be informal -as in social control, norms, and codes of behavior - or formal -such as written rules, contracts etc. Shared institutions among a group of agents provide stable conditions for knowledge transfer and interactive learning between agents. Thus, a certain level of institutional proximity covering a common language, shared habits, a law system securing intellectual property rights etc. is necessary for knowledge spillover (Boschma 2005). Similarly, social proximity refers to trust-based relationships which are embedded in different levels of social networks (Granovetter 1985) and considerably facilitates knowledge spillovers. Finally and most importantly, an agent can only benefit from a knowledge spillover only if he/she is able to decode the spilled knowledge. This situation refers to the absorptive capacity which is described as the ability to evaluate, to access and to assimilate outside knowledge (Cohen \& Levinthal 1990). Another way of looking at the absorptive capacity of agents is analyzing the cognitive proximity between them (Nooteboom 2000; Nooteboom et al. 2007). Empirical evidence suggest that inter-sectoral knowledge spillovers occur only when sectors in question are complementary in terms of competences (Frenken et al. 2007; Boschma \& Iammarino 2009). However, too much cognitive proximity may hinder interactive learning and real innovations, since no one offers something new to each other (Nooteboom et al. 2007). In sum, innovation activities require a certain level of cognitive, institutional and social proximities. Cluster-based innovation policies must therefore take into account these requirements which are not directly covered by the spatial proximity.

\section{Cluster-based Innovation Policies}

Following the shift to the knowledge-based economies, governments need also to transform their policies especially those relating to science, technology, education and industry. Acknowledging the importance of national innovation systems and the need for infrastructures and incentives, policies today need to prioritize enhancing knowledge diffusion, upgrading human capital and promoting organizational change (Foray 2004). National innovation systems bring together heterogeneous agents from industry, university and other knowledgegenerating institutions, whereas infrastructures and incentives encourage investments in research and training. Cluster-based innovation policies intend to tackle these priorities, particularly by providing the framework conditions for university-industry-government collaborations and by forwarding the diffusion of new technologies into various firms and sectors. While the cluster-based policies have gained high popularity during the past three decades, the cluster phenomenon has long been present in the economic system. Being closely located offers indeed many advantages which are described as "pecuniary externalities", which allows colocalized firms to access specialized inputs and labor at a lower price than rivals located elsewhere, on the one hand and "knowledge externalities", which we have previously analyzed in this paper (Krugman 1991). The earliest recognition of the role of innovation in a local context is made by Alfred Marshall during the late nineteenth and early twentieth centuries. His famous saying "the secrets of industry are in the air" indeed illustrates the localized knowledge spillovers. Nevertheless, spatial proximity isn't enough for knowledge to spill freely into the air, especially when knowledge as a collective activity is highly excludable to those outside of the network. In this paper, we are especially interested in clustering policies which are formulated to take advantage of the aforementioned externalities. In this regard, we discuss some measures at meso-level (firms- universitiesresearch institutes) and at micro-level (individuals moving from one organization to another).

Cluster-based innovation policies should not be limited to the provision of pecuniary advantages, which seems to be the case in most of the developing countries (Benner 2013). If the main objective behind these policies is to promote innovation, then they have to prepare the environment for knowledge externalities. More concretely, cluster-based innovation policies should aim the cognitive, institutional and social coordination. The cognitive coordination refers to the arrangements made to favor the knowledge generation. As discussed earlier in this paper, the knowledge generation process is defined as a collective activity bringing together heterogeneous agents holding each complementary bits of knowledge. This definition actually offers an important political implication at meso-level: cluster management must first classify the knowledge bases of firms and research 
institutes that apply to settle in cluster, and then accept only those agents which hold complementary bases. This approach refers to the idea of "related variety" which proves to be a significant variable for innovative efficiency (Asheim 2007; Frenken et al. 2007; Asheim et al. 2011). As for the institutional coordination, the best move is to build the cluster upon the existing institutional base. As Asheim et al. (2011) suggest, a regional policy should capitalize the region-specific assets and evolve on them, rather than select from a pool of policy recipes that were successful elsewhere. Regarding the innovation clusters, this suggestion implies gathering the agents that have a history of collaboration and thus share some specific institutions. Previous collaborations would also foster trust building between agents. In sum, innovation as a continuous interactive process can be supported by policies encouraging the emergence of a dynamic coordination at meso-level. The dynamic coordination relates to the creativity and adaptability of agents into different contexts during innovation process. More precisely, agents are able to change their roles and behaviors without disrupting the harmony of innovative activities they are undertaking. In this context, announcement of long-term programs of scientific and technological research, where public agencies are also involved, can encourage the alignment of research activities of firms and the emergence of complementarity (Antonelli 2005). These programs can also help employees of those agents to build social bonds that can foster reciprocal trust, which brings us to the instruments at micro-level.

Other than policy instruments at meso-level, cluster dynamism can be substantiated by the means of instruments involving individuals. Benner (2009), taking various studies on cluster theory, summarizes a number of mechanisms that can affect cluster dynamism in relation to innovative activities. These mechanisms especially point to the collective nature of knowledge generation process. More precisely they emphasize labor mobility among different institutions like universities, research institutes and firms within the clusters as well as individual relationships among members of these different institutions. The labor mobility can be observed in two types; first, involving only companies and, second, relating companies to research institutes or universities. The first category includes horizontal and vertical cooperation among companies or spin-off formations. Cooperations based on localized input-output relations can actually support interactive learning processes. Spinoff companies are also considered another source of knowledge spillovers insofar as they transfer recently created new knowledge to a new company. The second category of labor mobility is related to the links between academia and firms. It covers recruitment of qualified new staff among alumni of higher education, student work or internship in companies, cooperation between universities and companies. These different mechanisms involving labor mobility can indeed allow knowledge and experience transfer. Nevertheless, a rapid increase in productive innovation series is never granted once these mechanisms are put in place. As Breschi and Lissoni (2001) suggest, pure knowledge spillover can occur only when workers moving from one firm to another help in creating a common pool of knowledge in the new firm. Otherwise, labor mobility serves only the purpose of shifting the knowledge from one place to another, rather than spreading it. In order to create and take advantage of the knowledge spillover, the labor mobility must be supported by a set of common values and norms which allow the knowledge diffusion within companies. Other than workers moving from one firm to another or scientists entering into contractual arrangements with some existing firms or starting up their own firm, individual contacts between workers of different companies may be also indicated as a vehicle for knowledge spillover. Inasmuch as relationships between workers may be embedded in different social networks (Granovetter, 1985); knowledge transfers during innovative activities may also be conveyed through the contacts within these networks. In this regard, the cluster management can organize events outside of work environment, such as festivals, dinners, picnics etc., so that individuals employed in different organizations of the same cluster can forge different relationships with each other.

\section{Conclusion}

This paper discusses cluster-based innovation policies by focusing on the characteristics of innovation process. Innovation process is largely acknowledged as a collective and complex activity involving heterogeneous agents, and geographical proximity plays a key role in this process. Cluster-based innovation policies are thus developed and implemented considering this approach. By the means of these policies, policymakers are also hoping to take advantage of knowledge spillovers which are believed to increase the efficiency of innovation activities. Cluster policies may indeed act as an intermediary enabling knowledge spill over and diffuse across sectors. However, innovation activities require a certain level of cognitive, institutional and social proximities. Cluster-based innovation policies must therefore take into account these requirements which are not directly covered by the spatial proximity. With respect to the cognitive coordination, complementarity of knowledge bases held by the firms and other knowledge-generating organizations located in the cluster must be carefully surveyed by the cluster management. As for the institutional coordination, the best move is to build the cluster upon the existing institutional base. Finally, social coordination is closely related to the labor mobility policies. In sum, proposing only a workspace and financial incentives to high-tech companies is not enough to create a sustainable innovation cluster. The cluster must prepare the environment for its resident agents to build dynamic coordination mechanisms. It is only then the cluster can become the focal of a "learning region". 


\section{References}

- $\quad$ Acs, Z. J., Audretsch, D. B., \& Feldman, M. P. (1992). Real effects of academic research: comment. American Economic Review, 82/1: 363-7.

- _ _ (1994). R\&D spillovers and recipient firm size. The Review of Economics and Statistics, 76/2: 33640.

- $\quad$ Almeida, P., \& Kogut, B. (1999). Localization of knowledge and the mobility of engineers in regional networks. Management science, 45/7: 905-17.

- Antonelli, C. (2005). Models of knowledge and systems of governance. Journal of Institutional Economics, 1/1: 51-73.

- Arrow, K. J. (1962). Economic welfare and the allocation of resources for invention. Nelson R. R. (ed.) The rate and direction of inventive activity: Economic and social factors, pp. 609-26. Princeton University Press for N.B.E.R: Princeton, NJ.

- Asheim, B. (1996). Industrial districts as 'learning regions': a condition for prosperity. European planning studies, 4/4: 379-400.

- _ (2007). Differentiated knowledge bases and varieties of regional innovation systems. Innovation, 20/3: 223-41.

- Asheim, B., Boschma, R., \& Cooke, P. (2011). Constructing regional advantage: platform policies based on related variety and differentiated knowledge bases. Regional Studies, 45/7: 893-904.

- Asheim, B., Coenen, L., Moodysson, J., \& Vang, J. (2007). Constructing knowledge-based regional advantage: implications for regional innovation policy. International Journal of Entrepreneurship and Innovation Management, 7/2: 140-55.

- Asheim, B., \& Gertler, M. (2005). The geography of innovation: regional innovation systems. Fagerberg J., Mowery D. C., \& Nelson R. R. (eds) The Oxford handbook of innovation, pp. 291-317. Oxford University Press: Oxford.

- $\quad$ Audretsch, D. B., \& Feldman, M. P. (1996). R\&D spillovers and the geography of innovation and production. The American economic review, 630-40.

- Aydalot, P. (1986). Milieux innovateurs en Europe. Paris: GREMI.

- Becattini, G. (1992). Le district industriel: milieu créatif. Espaces et sociétés, 1: 147-64.

- Benner, M. (2009). What do we know about clusters? In search of effective cluster policies. SPACES online, 7/2009-04.

- _ - (2013). Cluster policy in developing countries. MPRA-Munich Personal RePEc Archive.

- Boschma, R. (2005). Proximity and innovation: a critical assessment. Regional studies, 39/1: 61-74.

- Boschma, R., \& Iammarino, S. (2009). Related variety, trade linkages, and regional growth in Italy. Economic Geography, 85/3: 289-311.

- Breschi, S., \& Lissoni, F. (2001). Knowledge spillovers and local innovation systems: a critical survey. Industrial and corporate change, 10/4: 975-1005.

- $\quad$ Brusco, S. (1986). Small firms and industrial districts: the experience of Italy. Keeble D. \& Weaver E. (eds) New firms and regional development in Europe, pp. 184-202. Croom Helm: London.

- Camagni, R. (Ed.). (1991). Innovation Networks: Spatial Perspectives. New York: John Wiley \& Sons, Inc.

- Cohen, W. M., \& Levinthal, D. A. (1990). Absorptive capacity: a new perspective on learning and innovation. Administrative science quarterly, 35/1.

- Cooke, P. (1992). Regional innovation systems: competitive regulation in the new Europe. Geoforum, 23/3: $365-82$.

- _ - (2001). Regional innovation systems, clusters, and the knowledge economy. Industrial and Corporate Change, 10/4: 945-74.

- Cooke, P., Gomez Uranga, M., \& Etxebarria, G. (1997). Regional innovation systems: Institutional and organisational dimensions. Research Policy, 26/4-5: 475-91.

- Feldman, M. P. (1994). The Geography of Innovation. Dordrecht, the Netherlands: Kluwer Academic Publishers.

- _ (1999). The new economics of innovation, spillovers and agglomeration: A review of empirical studies. Economics of innovation and new technology, 8/1-2: 5-25. 
- Feldman, M. P., \& Florida, R. (1994). The geographic sources of innovation: technological infrastructure and product innovation in the United States. Annals of the Association of American Geographers, 84/2: 21029.

- $\quad$ Foray, D. (2004). Economics of Knowledge. Cambridge, MA: MIT Press.

- $\quad$ Foray, D., \& Lundvall, B. A. (1998). The knowledge-based economy: from the economics of knowledge to the learning economy. The economic impact of knowledge, 115-21.

- $\quad$ Frenken, K., Van Oort, F., \& Verburg, T. (2007). Related variety, unrelated variety and regional economic growth. Regional studies, 41/5: 685-97.

- $\quad$ Fritsch, M., \& Stephan, A. (2005). Regionalization of innovation policy-Introduction to the special issue. Research Policy, 34/8: 1123-7.

- Granovetter, M. (1985). Economic action and social structure: the problem of embeddedness. American journal of sociology, 91/3: 481-510.

- _ (2005). The impact of social structure on economic outcomes. The Journal of Economic Perspectives, 19/1: 33-50.

- Von Hippel, E. (1994). 'Sticky information' and the locus of problem solving: implications for innovation. Management science, 40/4: 429-39.

- Jaffe, A. B. (1989). Real effects of academic research. The American Economic Review, 957-70.

- Jaffe, A. B., Trajtenberg, M., \& Henderson, R. (1993). Geographic localization of knowledge spillovers as evidenced by patent citations. the Quarterly journal of Economics, 108/3: 577-98.

- Krugman, P. (1991). Geography and trade. Cambridge, MA: MIT Press.

- Lundvall, B. (1988). Innovation as an interactive process: from user-producer interaction to the national system of innovation. Dosi G., Freeman C., Nelson R. R., Silverberg G., \& Soete L. L. (eds) Technical Change and Economic Theory, pp. 349-69. Pinter: London.

- _ _ (2009). Innovation as an interactive process: user-producer interaction to the national system of innovation: research paper. African journal of science, technology, innovation and development, $1 / 2 \& 3$ : 10-34.

- Lundvall, B., \& Johnson, B. (1994). The learning economy. Journal of Industry Studies, 1/2: $23-42$.

- Morgan, K. (1997). The learning region: institutions, innovation and regional renewal. Regional studies, 31/5: 491-503.

- Nelson, R. R. (1959). The Simple Economics of Basic Scientific Research. The Journal of Political Economy, 67/3: 297-306.

- Nooteboom, B. (2000). Learning by interaction: absorptive capacity, cognitive distance and governance. Journal of Management and Governance, 4/1-2: 69-92.

- Nooteboom, B., Van Haverbeke, W., Duysters, G., Gilsing, V., \& Van den Oord, A. (2007). Optimal cognitive distance and absorptive capacity. Research Policy, 36/7: 1016-34.

- North, D. C. (1990). Institutions, institutional change and economic performance. Cambridge University Press.

- $\quad$ Polanyi, M. (1958). Personal Knowledge: ‘Towards a Post-Critical Philosophy’. London: Routledge \& Kegan Paul Ltd.

- Rondé, P., \& Hussler, C. (2005). Innovation in regions: What does really matter? Research Policy, 34/8: 1150-72. DOI: 10.1016/j.respol.2005.03.011

- Tödtling, F., \& Trippl, M. (2005). One size fits all?: Towards a differentiated regional innovation policy approach. Research Policy, 34/8: 1203-19.

- Torré, A., \& Gilly, J. P. (1999). On the analytical dimension of proximity dynamics. Regional studies, 34/2: 169-80.

- Tsai, W. (2001). Knowledge transfer in intraorganizational networks: Effects of network position and absorptive capacity on business unit innovation and performance. Academy of management journal, 44/5: 996-1004. 